\title{
Tumor necrosis factor alpha as a potential marker for prostate cancer
}

\author{
M. S. Ali \\ Salwa H. N. Al-Rubae'i * \\ Najwa Shihab Ahmed ** \\ Chemistry department / Applied Science College / University of Technology \\ * College of Science / Mustansiriya University \\ ** Biotechnology Research Centre / Molecular and Biotechnology Laboratory / Al-Nahrain University \\ E-mail: Wahj_dna@yahoo.com
}

\begin{abstract}
:
Background: Prostate cancer is currently the most common cause of cancer death in men. The exact cause of developing prostate cancer is not known though inflammation, ageing, ethnicity and heredity are important factors involved in the initiation and development of this cancer.

Aim of study : The aim of this study to determine the levels of prostate specific antigen (PSA), tumor necrosis factor alpha (TNF- $\alpha$ ), testosterone (T) and dihydrotestosterone (DHT) in sera of thirty patients with prostate cancer (PCa), thirty patients with benign prostate hyperplasia (BPH) and in thirty health volunteers, T/DHT ratio was also calculated.

Result: There was a significant increase in the levels of PSA, TNF- $\alpha$, T and T/DHT ratio in PCa as well as BPH patients compared to the controls. There was a significant decrease in DHT levels in both PCa and BPH compared to the controls.

Conclusion: TNF- $\alpha$ could serve as a potential marker for the diagnosis of PCa.
\end{abstract}

Keywords: prostate cancer, benign prostate hyperplasia, TNF- $\alpha$, testosterone, dihydrotestosterone.

Introduction:

PCa remains one of the most universal malignant tumors and the major cause of cancer-associated death in the male worldwide (1). The incidence of PCa may vary among different ethnic groups and countries. BPH is a common symptom of the urinary system in old age $(2,3)$. BPH is characterized by a non-malignant enlargement of the prostate gland due to the uncontrolled proliferation of smooth muscle and epithelial cells located in the periurethral transition zone of the prostate gland surrounding the urethra $(4,5)$. Chronic inflammation has been implicated in the development of complex human diseases including PCa and BPH. Cytokines are important inflammatory markers secreted in response to tumors and often by tumor cells. Also, the initial stages of the disease have been linked to hormonal stimuli, notably the anabolic steroid, T. T molecules enter the prostatic cell by diffusion; after that, about $90 \%$ of $\mathrm{T}$ molecules are converted by the enzyme 5-alpha-reductase $(5 \alpha-\mathrm{R})$ to DHT which is the main tissue androgen involved in the growth of the adult prostate (6). DHT and remaining T molecules bind to the androgen receptor, which is activated and translocated to the nucleus which binds to androgen-response elements in the DNA of prostate cells, ultimately inducing proliferation (7). TNF- $\alpha$, a proinflammatory cytokine can activate the oncogenic transcription factors like NF-jB and AP-1 in cells. These factors further accelerate proliferation, antiapoptotic activity, and inflammation reaction. Epidemiologic and molecular evidence has supported the key role of TNF- $\alpha$ in both inflammatory and cancer-promoting pathway in various cancer like oral, breast $(8,9)$ and prostate (10). This study aims to investigate the hormonal profile in the pathogenesis of PCa and the possibility of using TNF- $\alpha$ as a marker for the diagnosis of PCa.

Materials \&Methods:

Study subjects

A case-control study was conducted on sixty male patients, were enrolled from Ghazi Al-Hariri hospital/Medical City/Baghdad, Iraq. Thirty of which were diagnosed with PCa and thirty with BPH with ages ranged (45-86) and (46-91) years respectively. Besides, thirty apparently healthy volunteers their ages ranged between (41-86) years were selected and served as control. The study was done during the period from February 2018 to January 2019, in Baghdad, Iraq.

\section{Exclusion criteria}

These include the followings; Patients under chemo or radiotherapy, Patient who underwent prostatectomy, Patients with different cancers, Patients with any type of inflammation and Diabetic patients.

\section{Sample collection}

Ten ml of venous blood samples were collected from thirty PCa patients, thirty patients with BPH and from thirty controls. Serum samples were separated and stored at $-20{ }^{\circ} \mathrm{C}$ until assayed. 


\section{Measurement of PSA serum levels}

PSA serum levels were measured using the ARCHITECT i1000 SR PSA kit (Abbott/Ireland) according to the manufacturer's instructions.

\section{Measurement of TNF- $\alpha$ serum levels}

TNF- $\alpha$ serum levels were measured using TNF- $\alpha$ ELISA Kit (Invitrogen/USA) according to the manufacturer's instructions.

\section{Measurement of testosterone serum levels}

Testosterone serum levels were measured using Testosterone ELISA Kit (VEDALAB/France) according to the manufacturer's instructions.

\section{Measurement of dihydrotestosterone serum levels}

Dihydrotestosterone serum levels were measured using the dihydrotestosterone ELISA Kit (Demeditec /Germany) according to the manufacturer's instructions.

\section{Statistical analysis}

The statistical package for social sciences (SPSS V. 25) was used to analyze the biochemical data.

\section{Results and discussion}

Serum levels of PSA, TNF- $\alpha, \mathrm{T}$ and T/DHT ratio measured in PCa, BPH and controls are shown in Table (1).

Table (1): serum levels of PSA, TNF- $\alpha$, $T$ and T/DHT ratio measured in PCa, BPH and controls

\begin{tabular}{|c|c|c|c|c|c|c|}
\hline \multirow[t]{2}{*}{ parameters } & \multirow{2}{*}{$\begin{array}{c}\text { PCa }(\text { mean } \pm \text { SD }) \\
\text { A }\end{array}$} & \multirow{2}{*}{$\begin{array}{c}\text { BPH }(\text { mean } \pm \text { SD }) \\
\text { B }\end{array}$} & \multirow{2}{*}{$\begin{array}{c}\text { Control (mean } \pm \text { SD) } \\
\text { C }\end{array}$} & \multicolumn{3}{|c|}{ p-value } \\
\hline & & & & A vs C & B vs C & A vs B \\
\hline PSA (ng/mL) & $47.419 \pm 28.495$ & $10.079 \pm 5.501$ & $0.488 \pm 0.461$ & 0.000* & $0.029 *$ & $0.000^{*}$ \\
\hline TNF- $\alpha(\mathrm{pg} / \mathrm{mL})$ & $44.468 \pm 20.187$ & $23.513 \pm 0.865$ & $20.806 \pm 0.719$ & 0.000* & NS & $0.000^{*}$ \\
\hline$T(\mathrm{ng} / \mathrm{mL})$ & $13.222 \pm 3.615$ & $9.657 \pm 1.614$ & $5.620 \pm 2.711$ & $0.000 *$ & $0.000^{*}$ & $0.000^{*}$ \\
\hline DHT (pg/mL) & $176.86 \pm 88.622$ & $228.98 \pm 74.807$ & $306.73 \pm 185.44$ & 0.000* & $0.019 *$ & NS \\
\hline T/DHT & $87.110 \pm 38.028$ & $46.379 \pm 17.406$ & $22.431 \pm 13.916$ & 0.000* & 0.000* & $0.000^{*}$ \\
\hline
\end{tabular}

* Significant at $\mathbf{P}<0.05$, NS: Non-significant at p>0.05, PCa: prostate cancer, BPH: benign prostate hyperplasia.

These results showed a highly significant increased in PSA serum levels $(47.41 \pm 28.49)$ and $(10.07 \pm$ 5.50) for PCa and $\mathrm{BPH}$ patients groups respectively as compared to control group $(0.48 \pm 0.46)$. The results also showed a highly significant increased in TNF- $\alpha$ serum levels $(44.468 \pm 20.187)$ for PCa and no significant increased $(23.513 \pm 0.865)$ for $\mathrm{BPH}$ patients groups respectively as compared to control group $(20.806 \pm 0.719)$. These results revealed a highly significant increased in T serum levels $(13.222 \pm 3.615)$ and $(9.657 \pm 1.614)$ for PCa and BPH patients groups respectively as compared to control group (5.620 \pm 2.711). The results also revealed a significant increased in DHT serum levels $(176.86 \pm 88.622)$ and $(228.98$ $\pm 74.807)$ for $\mathrm{PCa}$ and $\mathrm{BPH}$ patients groups respectively as compared to control group (306.73 \pm 185.44$)$. The results also showed a highly significant increased $(\mathrm{P}=0.000)$ in T/DHT ratio $(87.110 \pm 38.028)$ and

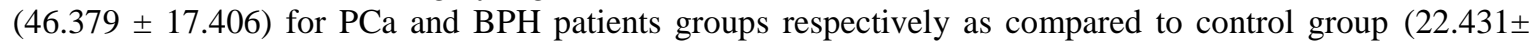
13.916).

Various examinations have demonstrated that patients with prostate malignant growth have in general raised serum PSA levels concerning men without the prostate disease. In any case, the risk of malignancy is relative to the serum PSA level even at concentrations less than $4 \mathrm{ng} / \mathrm{mL}$. With a serum PSA level under 2 $\mathrm{ng} / \mathrm{mL}$, the likelihood of malignant growth is under $2 \%$, it is increased to about $18 \%$ when the PSA serum level is 2.5 to $4.0 \mathrm{ng} / \mathrm{mL}$. Several trial studies showed that significant cancers in patients with serum PSA levels of 2.5 to $4.0 \mathrm{ng} / \mathrm{mL}$, a few specialists have proposed bringing down the PSA cutoff to $2.5 \mathrm{ng} / \mathrm{mL}$ to 
improve the early discovery of the disease in younger men (11). Because of benign prostate tissue secrete PSA, therefore, the serum level of PSA is not considered a diagnostic for prostate cancer. Different factors, for example, prostatitis, infarct and instrumentation of the prostate elevate serum PSA levels $(12,13)$.

Inflammation has now been recognized to contribute to proliferation, malignancy, angiogenesis, metastasis, modulation of adaptive immunity, and unresponsiveness to hormones and chemotherapeutic agents (14). TNF- $\alpha$ is a proinflammatory cytokine, that is associated with cancer progression. There has been a study by (15), where TNF- $\alpha$ is associated with prostate cancer progression. Serum TNF- $\alpha$ activity was positive in $76 \%$ of the patients with relapsed disease who had a significantly higher mortality rate than those with undetectable serum TNF- $\alpha$ levels. The expression and action of TNF- $\alpha$ and its receptors has been reported in several tumors such as esophageal (16), prostate (17), follicular thyroid (18), ovarian (19) and breast (20) cancers. A study reported elevated serum levels of the TNF- $\alpha$ in patients with prostate cancer as compared with controls. Their results showed that there was a strong association between the serum levels of the cytokine, disease stage and the presence of metastatic disease (21). TNF- $\alpha$ was significantly elevated in patients with metastatic cancer compared with the two groups of patients with localized disease and controls and was correlated with increasing PSA. In patients with progressive disease, TNF- $\alpha$ levels were elevated at the point of biochemical progression and further raised at symptomatic progression. Michalaki et al. concluded that TNF- $\alpha$ may, therefore, provide an additional marker to PSA that reflect the activity of prostate cancer, they postulated that serum TNF- $\alpha$ levels might be useful prognostic markers concerning progression to biochemical or symptomatic relapse based on the results of serial measurements.

In the adult human, serum $\mathrm{T}$ level is 10 times higher than serum DHT level. In contrast, the level of intraprostatic DHT is at least five times higher than the level of intraprostatic T (22). The most important source of DHT in the human body is the prostate, particularly prostatic stroma, which produces 10 times more DHT than epithelium $(23,24)$. The development of benign prostate hyperplasia (BPH) depends on the interaction between stromal and epithelial cells. This process includes the progressive production of DHT and the synthesis of growth factors (GFs) and survival factors (SFs) in fibroblasts and their influence on the proliferation and protein synthesis in the epithelial cells (25). From the clinical point of view, a prostate is considered enlarged when its volume exceeds $31 \mathrm{~mL}(26)$. The current literature lacks definite data on the intraprostatic levels of T and DHT, due to different methods of tissue retrieval and chemical analyses. However, the current opinion is that intraprostatic DHT concentrations are maintained but not elevated in $\mathrm{BPH}$, while there is an absence in similar data concerning intraprostatic $\mathrm{T}$ concentrations $(27,28)$, The results of the present research are in accordance to some of the results mentioned in the literature stating that increased levels of testosterone are associated with increased risk of prostate cancer. In the retrospective Physicians' Health Study (612 cases) a strong trend of increasing PCa risk was observed with increasing total $\mathrm{T}$ when hormones and Sex hormone-binding globulin were adjusted simultaneously (29). In a previous study, 420 patients who underwent prostate biopsy and had a PSA $<10 \mathrm{ng} / \mathrm{ml}$, pretreatment total $\mathrm{T}$ was significantly higher in patients diagnosed with PCa ( $\mathrm{p}=0.007)$ (30). A meta-analysis restricted to only two studies that performed mutual adjustment for all measured serum hormones, age, and body mass index indicated that men whose total $\mathrm{T}$ was in the highest quartile were 2.34 times more likely to develop PCa (31). Surprisingly, in a cohort of 724 patients who underwent radical prostatectomy, high-risk of recurrent PCa (tumors stage $>$ T3a; Gleason score $(32)$ or PSA $>20 \mathrm{ng} / \mathrm{ml}$ ) was significantly more frequent both for the lowest and the highest-circulating $\mathrm{T}(\mathrm{p}=0.03)$, depicting a nonlinear $\mathrm{U}$-shaped risk behavior (33).

\section{Conclusions}

TNF- $\alpha$ in addition to PSA may serve as a potential marker for the diagnosis of PCa in cases where PSA is not significantly correlated with PCa. Decreased DHT along with increased T levels as well as T/DHT ratio could be associated with increased risk of PCa.

\section{Acknowledgement}

We deeply thank the Ministry of Higher Education and Scientific Research, Iraq for its support and funding this project to help the authors in achieving it at Mustansiriyah University, College of Science, Chemistry Department, Biochemistry laboratory.

\section{Conflict of interests}

The authors declare that they have no conflict of interests. 


\section{References}

1. Xi L, Lu C, Yinghui F, Yi H, Xiaoqun Y, Yao L, Jianlei L, Jianmin L, Xiuwu P, Fajun Q, Xingang C, Yi G, Danfeng X. IFITM3 promotes bone metastasis of prostate cancer cells by mediating activation of the TGF- $\beta$ signaling pathway. Cell Death and Disease. (2019); 10: 517.

2. Pyo JS, Cho WJ. Systematic review and meta-analysis of prostatic artery embolisation for lower urinary tract symptoms related to benign prostatic hyperplasia. Clin Radiol. (2017); 72:16-22.

3. Cornu J, Ahyai S, Bachmann A, de la Rosette J, Gilling P, Gratzke C, McVary K, Novara G, Woo H, Madersbacher S. A systematic review and meta-analysis of functional outcomes and complications following transurethral procedures for lower urinary tract symptoms resulting from benign prostatic obstruction: an update. Eur Urol. (2015); 67: 1066-1096.

4. Aaron L, Franco O, Hayward S. Review of prostate anatomy and embryology and the etiology of benign prostatic hyperplasia. Urol Clin North Am. (2016); 43: 279-288.

5. Strand D, Costa D, Francis F, Ricke W, Roehrborn C. Targeting phenotypic heterogeneity in benign prostatic hyperplasia. Differentiation. (2017); 96: 49-61.

6. Sinisi A, Pasquali D, Notaro A, Bellastella A. Sexual differentiation. J Endocrinol Invest. (2003); $26: 23-28$.

7. Ross A, Rodriguez R. Development, molecular biology, and physiology of the postate. In: Wein AJ, editorin-chief. Kavoussi LR, Partin AW, Peters CA, eds. Campbell-Walsh Urology. Philadelphia: Elsevier. (2016); 2393-2424.

8. Bandil K, Singhal P, Sharma U, Hussain S, Basu S, Parashari A. Impacts of TNF-LTA SNPs/haplotypes and lifestyle factors on oral carcinoma in an indian population. Mol Diagn Ther. (2016); 20: 469-480.

9. Korobeinikova E, Myrzaliyeva D, Ugenskiene R, Raulinaityte D, Gedminaite J, Smigelskas K, Juozaityte E. The prognostic value of IL10 and TNF alpha functional polymorphisms in premenopausal early-stage breast cancer patients. BMC Genet. (2015); 16: 70.

10. Brian W, Kieran F, Pamela J. Paradoxical Roles of Tumour Necrosis Factor-Alpha in Prostate Cancer Biology. Prostate Cancer. (2012); 2012:128965.

11. Gretzer MB , Partin AW. PSA markers in prostate cancer detection. Urol Clin North Am. (2003); 30: 677686.

12. Mary WD. Prostate Cancer Screening. Semin Oncol Nurs. (2017); 33(2):156-164.

13. Jyoti S, Blacke C, Patil P, Amblihalli V, Nicholson A. Prostate cancer screening by prostate-specific antigen (PSA); a relevant approach for the small population of the Cayman Islands. Cancer Causes Control. (2017); 29(1):87-92.

14. Hanahan D, Weinberg R. "Hallmarks of cancer: the next generation." Cell. (2011); 144(5): 646-674.

15. Nakashima J, Tachibana M, Ueno M, Miyajima A, Baba S, Murai M. Association between tumor necrosis factor in serum and cachexia in patients with prostate cancer. Clin Cancer Res. (1998); 4: 1743-1748.

16. Hubel K, Mansmann G, Schafer H, Oberhauser F, Diehl V, Engert A. Increase of anti-inflammatory cytokines in patients with esophageal cancer after perioperative treatment with G-CSF. Cytokine. (2000); 12:1797-800.

17. De Miguel M, Royuela M, Bethencourt F, Santamar1'a L, Fraile B, Paniagua R. Immuno-expression of tumour necrosis factor- $\alpha$ and its receptors 1 and 2 correlates with proliferation/apoptosis equilibrium in normal, hyperplasic and carcinomatous human prostate. Cytokine. (2000); 5: 535-538.

18. Zubelewicz B, Muc-Wierzgon M, Wierzgon J, Romanowski W, Mazurek U, Wilczok T, Podwinska E. Genetic disregulation of gene coding tumor necrosis factor alpha receptors (TNF alpha Rs) in follicular thyroid cancer-preliminary report. J Biol Regul Homeost Agents. (2002); 16: 98-104.

19. Rzymski P, Opala T, Wilczak M, Wozniak J, Sajdak S. Serum tumor necrosis factor alpha receptors $\mathrm{p} 55 / \mathrm{p} 75$ ratio and ovarian cancer detection. Int J Gynaecol Obstet. (2005); 88: 292-298.

20. Garcia-Tuñon I, Ricote M, Ruiz A, Fraile B, Paniagua R, Royuela M. Role of tumor necrosis factor-alpha and its receptors in human benign breast lesions and tumors (in situ and infiltrative). Cancer Sci. (2006); 97:1044-1049.

21. Michalaki V, Syrigos K, Charles P, Waxman J. Serum levels of IL-6 and TNF-a correlate with clinicopathological features and patient survival in patients with prostate cancer. British Journal of Cancer. (2004); 90: $2312-2316$.

22. Berman D, Rodriguez R, Veltri R. Development, molecular biology, and physiology of the prostate. In: Wein AJ, editor-in-chief. Kavoussi LR, Partin AW, Peters CA, Novick AC, eds. Campbell-Walsh Urology. Philadelphia: Saunders. (2012); 2533-2569. 
23. Rennie P, Bruchovsky N, McLoughlin M, Batzold F, Dunstan- Roehrborn C. Benign prostatic hyperplasia: etiology, pathophysiology, epidemiology, and natural history. In: Wein AJ, editor-in-chief. Kavoussi LR, Partin AW, Peters CA, eds. Campbell-Walsh Urology. Philadelphia: Elsevier. (2016); 2425-2462.

24. Olsson M, Ekström L, Guillemette C, Belanger A, Rane A, Gustafsson O. Correlation between circulatory, local prostatic, and intra-prostatic androgen levels. Prostate. (2011); 71: 909-914.

25. Lee K, Peehl D. Molecular and cellular pathogenesis of benign prostatic hyperplasia. J Urol. (2004); 172:1784-1791.

26. Crawford E, Wilson S, McConnell J, Slawin K, Lieber M, Smith J, Meehan A, Bautista O, Noble W, Kusek J, Nyberg L, Roehrborn C. MTOPS RESEARCH Group. Baseline factors as predictors of clinical progression of benign prostatic hyperplasia in men treated with placebo. J Urol. (2006); 175:1422-1426; discussion 1426-7.

27. Pejčić T, Tosti T, Tešić Ž, Milković B, Dragičević D, Kozomara M, Čekerevac M, Džamić Z. Testosterone and dihydrotestosterone levels in the transition zone correlate with prostate volume. The Prostate. (2017); 77(10): 1082-1092.

28. Roehrborn C. Benign prostatic hyperplasia: etiology, pathophysiology, epidemiology, and natural history. In: Wein AJ, editor-in-chief. Kavoussi LR, Partin AW, Peters CA, eds. Campbell-Walsh Urology. Philadelphia: Elsevier. (2016); 2425-2462.

29. Gann PH, Hennekens CH, Ma J, Longcope C, Stampfer M. JProspective study of sex hormone levels and risk of prostate cancer. J Natl Cancer Inst. (1996); 88: 1118.

30. Yano M, Imamoto T, Suzuki H, Fukasawa S, Kojima S, Komiya A, Naya Y, Ichikawa T. The clinical potential of pretreatment serum testosterone level to improve the efficiency of prostate cancer screening. Eur Urol. (2007); 51: 375.

31. Shaneyfelt T, Husein R, Bubley G, Mantzoros C. Hormonal predictors of prostate cancer: a metaanalysis. J Clin Oncol. (2000); 18: 847.

32. Muller R, Gerber L, Moreira D, Andriole G, Castro-Santamaria R, Freedland S. Serum testosterone and dihydrotestosterone and prostate cancer risk in the placebo arm of the Reduction by Dutasteride of Prostate Cancer Events trial. Eur Urol. (2012); 62: 757-764.

33. Izumi K, Shigehara K, Nohara $\mathrm{T}$, Narimoto $\mathrm{K}$, Kadono $\mathrm{Y}$, Mizokami A. Both High and Low Serum Total Testosterone Levels Indicate Poor Prognosis in Patients with Prostate Cancer. Anticancer Res. (2017); 37(10): 5559-5564. 